\title{
変形菌による実験的ラット逆行性腎孟腎炎に関する研究
}

\author{
第 1 報 同一腎より病理組織標本と腎内全菌数の両者を得乃試み \\ 岡山大学医学部泌尿器科教室 高任本均
(主任: 大森弘之教授)
}

\section{STUDIES ON RETROGRADE PROTEUS MIRABILIS PYELONEPHRITIS IN THE RAT.}

I. An Experiment to Obtain Both Pathologic Sections and Total

Number of Bactdria from one Kidney Simultaneously.

Hitoshi Takamoto

Department of Urology, Okayama University Medical School, Okayama

(Director: Prof. H. Ohmori)

It has been difficult to obtain simultaneously the preparation of pathologic section and the total number of bacteria from the infected kidney. The present study was performed to solve this problem in retrograde Proteus mirabilis pyelonephritis in rats. Infected kidneys were removed aseptically five days after inoculation of the bacteria, and immediately frozen at $-70^{\circ} \mathrm{C}$, then some thin sections were obtained from the bisected kidneys using a cryostat. All of the remaining tissues including the chips of the frozen section were used for counting the total number of bacteria in the kidneys. The decrease in number of bacteria in the kidneys was negligible after preservation at $-20^{\circ} \mathrm{C}$ for 48 hours. The degree of renal lesions were graded pathologically according to the classification of Arana et al. modified by Araki et al. The total number of bacteria in the infected kidney had a good correlation with the pathological grading $(\mathrm{p}<0.001)$.

The results indicate that this method is excellent for both obtaining samples for pathologic sections and counting the total number of bacteria from one kidney, and that the pathological grading of infected kidneys is very useful in showing the degree of infection in the experimental retrograde pyelonephritis in rats, with this, in the acute stage without treatment, wanting the total number of bacteria in the kidney is thonght to be omitted.

要旨: 実験的腎㙉腎炎に扔いて, 同一腎より病理組織標本と菌数の両者を得る従来の力法にはどちらかを多少 犠牲にするという不満足な点があつた。そこで実験的ラット逆行性腎歪婜炎に拈いて，この点を克服すること

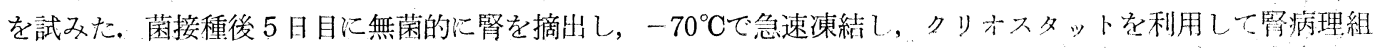
織標本を作製した，残腎組織は削片も全て含めてー20 Cで48時間凍結保存後，菌数測定に使用に，ほほ腎内全 菌数を求めた， $-20^{\circ} \mathrm{C} ， 48$ 時間凍結保存によ万腎内菌数の減少は無視し得た。腎病理組織学的所見はA Arana らの分類を修正した荒木らの分類に従つて Grade 分けを行はつた，腎内全菌数と腎病変の Grade は上く並行 し, 各 Grade の平均菌数間には有意差を認めた。

上記結果より本法は，同一腎より病理組織標本と腎内全菌数の雨者を得るのに良い方法であると考えられ る. また, 同分類法は実験的ラット逆行性腎孟腎炎の重症度判定に有用であり, 少なくとも急性期で抗菌剂投 与等の処置を施していない場合は, 腎内菌数も省略し得ると考兄られる.

\section{緒言}

垁験的感染症における宿主の防御能や感染の重症度, 治療効果を判定する場合, 炎症栄の肉眼的, 病理組織学
的検討と共に，菌数がまず問題となる．実験的逆行性腎

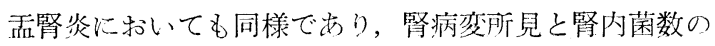
両者を検索する方法が種々行なわれている。その方法に 
は大別して 2 通りあり，1つは，腎病变の病理組織学的 所見を得るため, 婜を切半して一方を組織標本に，他方

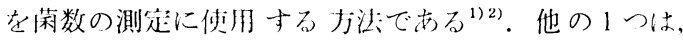
掔病变は肉眼的所見にとどめ，婜全休を菌数の測定に使 用する才法である ${ }^{324)}$ 。しかし，前者は逆行性腎南腎炎の 病変が必ずしも婜全域に一様には牛じないといら点で， 半切した婜の・少のみの获数をもつて，一腎全体の菌数 茄るいは㹂組織 $1 \mathrm{~g}$ 当りの菌数を算定するのは正確でな い.一方，後者は婜内菌数には閶題ないが，腎病変の狱 理組織学的所見が得ら机ないという久点がある。また， 促来菌数の測定は腎摘出後古ちに行なわれていたため時 闰的な制約があり，小人数で実験を行なら場合には，必 要とする他の尖験に時間がさけないららみがあつた。 そ こで，著者は，棒験的ラット逆行性腎血腎炎で，腎のほ ぼ全量を菌数測定に使用すると共に，その極一部を組織 標本に使用できないかと考え，組織標本はクリオスタッ 卜を使用して凍絬切片より作製し，残存組織は削片も食 て含めて後日の菌数測定に使用することを試みた。

\section{実験材料および方法}

（1）ラット拈よび起炎藏

日本ラット K.K. (浦和市) から購人した雌ドンリ ューラット（生後 5 週，体車 $100 \sim 120 \mathrm{~g}$ ）を用いた。起 炎菌は臨林分離の Proteus mirabilis (当教室番号 $228 \mathrm{~L}$ 怢，以下 $\mathrm{Pm}$ と略す）を用いた。

（2）逆行性腎面腎炎の作成拉上び居殺

荒本 ${ }^{5)}$ の方法に從い，経膀胱的に Pm $2 \sim 4 \times 10^{7}$ 個 を接種した。企例 $\mathrm{Pm}$ 接種後5 日目にエーテル麻酔卜 に開腹し, 腹部大動脈より脱血後, 腎, 膀脂を無菌的に 摘出した。婜は艮軸に汾つて切半し，膀脱は半比してデ ゾキショレート培地（ニッスイ）に涂有し，Pm の榆 出，问定を行なつた。督は肉眼的観察と重量計測を行な つた。

（3）腎組織標本の作製

㹂は切半面をトにして，真鍮製金属ブロック（24× $18 \times 6 \mathrm{~mm})$ に接着させた。 切半腎で肉眼的病変の程度に 差のある場合は，高度病変側を使用した．金属ブロック に接着させた腎は，採取したい組織部位まで表面の組織 をハサミで水平に切除した。以上の操作はすべて無菌的 にアルミシャーレ（内径 $60 \mathrm{~mm}$, 深さ $14 \mathrm{~mm}$ ) 内で行な つた，金属ブロックに真鍮を用いたまな理由は，真鍮は 熱伝導㻭が艮く、さびにくいことである。腎組織は金属

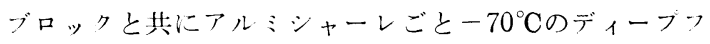

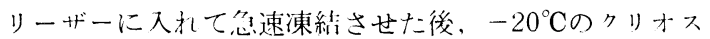

タットに移した，腎組織を接着させた金属ブロックを無 菌的に取り出し, ニング型ミクロトームにて, 原則と

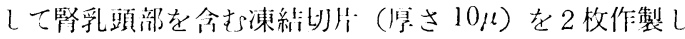
た、人スは备婜ごとに70\%アルッールで消毒後, 隇菌

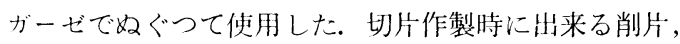
および金属ブロックに残存した組織は食て無菌的にアル シシャーレに回収した。凍絬切扸は95\%アルュールで战 定，水洗し，H.E. 染色を行なつた。残腎組織を回収し たアルミシャーレはー $20^{\circ} \mathrm{C}$ 冷凍庫に保存した。

(4) 婜内苗获数測分:

腎組織は凍結48時閒後に案温で解凍後，直ちに，腎重 㫣の 4 倍最の生食水を加兄, 容量 $10 \mathrm{ml}$ のテフロンホモ ジナイザーを用いてホモジナイズした。つまり原液は腎 組織を5 倍に希秋したことになる。原液から10-6まで の10倍希釈液を作り，各々をデジキショレート培地に $\mathrm{lml}$ ずつ希釈し、各 2 枚のブレートを作製した。プレー

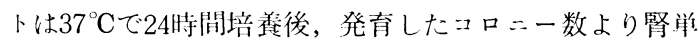
位の菌数を算定したあある程度実験が進んだ後は，原則 として肉腿的に婜膿瘍を有する場合は $10^{-4}, 10^{-5}, 10^{-6}$ 侨积液，腎荋内に膿を有する場合は $10^{-3}, 10^{-4}, 10^{-5}$, 掔血内に変化を認めないが婜割面より Pmを検出した 場命は $10^{-2}, 10^{-3}, 10^{-4}$, 㹂制涌より $\mathrm{Pm}$ を検出しなか つた場合には原液について，齐々2 枚のプレートを作製 して菌数計算を行なつた。

\section{結 果}

（1）菌数測定に歺之る凍結保存の影響

a) TSB (Tripticase soy broth-BBL) 巾の菌数: Pm を TSB で $37^{\circ} \mathrm{C}$ ，18時間培養後䔉数を測定した。间 一液 をー $20{ }^{\circ} \mathrm{C} て ゙ 2$ 週閒および 1 力月閏凍結保存後, 再度莯数 を測定した，TSB 巾の菊数は，2週間の涷絬保存では变

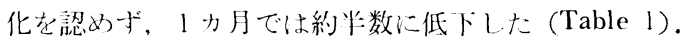

b）腎内全菌数：Pm 接種後 5 日目のラットで腎膿揚 在有する 6 腎のらち，2腎（No.1，2）は摘出後直ちに ホモジナイズし菌数を測定した。同ホモジナイズ液の 部を $-20^{\circ} \mathrm{C} て ゙ 48$ 時間凍結保存後, 再度菌数を測定した。

Table 1 Variance of number of bacteria in TSB after the preservation at $-20^{\circ} \mathrm{C}$

\begin{tabular}{|c|c|}
\hline $\begin{array}{l}\text { Preservation period } \\
\text { Before preservation }\end{array}$ & No. of organisms (per ml) \\
\hline 2 weeks & $4.6 \times 10^{8}$ \\
\hline 1 month & $5.6 \times 10^{8}$ \\
\hline
\end{tabular}


Table 2 Total numer of bacteria in the kidneys with abscesses

\begin{tabular}{c|c|c}
\hline No. of case & \multicolumn{2}{|c}{ No. of organisms per kidney } \\
\hline 1 & $5.3 \times 10^{7} \mathrm{a}$ & $4.1 \times 10^{6} \mathrm{~b}$ \\
\hline 2 & $9.7 \times 10^{7} \mathrm{a}$ & $1.7 \times 10^{6} \mathrm{~b}$ \\
\hline 3 & $1.1 \times 10^{7} \mathrm{c}$ & $4.3 \times 10^{4} \mathrm{~d}$ \\
\hline 4 & $1.5 \times 10^{7} \mathrm{c}$ & $4.2 \times 10^{4} \mathrm{~d}$ \\
\hline 5 & $2.2 \times 10^{7} \mathrm{c}$ & $6.4 \times 10^{4} \mathrm{~d}$ \\
\hline 6 & $3.4 \times 10^{6} \mathrm{c}$ & $2.2 \times 10^{4} \mathrm{~d}$ \\
\hline
\end{tabular}

a: homogenized immediately after nephrectomy $\mathrm{b}$ : after the preservation of homogenized kidney at $-20^{\circ} \mathrm{C}$ for 48 hours

$c:$ homogenized after the preservation of bisected kidney at $-20^{\circ} \mathrm{C}$ for 48 hours

$\mathrm{d}$ : after the represervation of homogenized kidney at $-20^{\circ} \mathrm{C}$ for 4 days
この場合は，菌数は $10^{1}$ 代の低下を認めた。 また他の 4 粲 (No. 3〜6) はー $20^{\circ} \mathrm{C}$ で48時間凍結保存後ホモジナイ ズし菌数を測定しれ。さらに同ホモジナイズ夜の一部を 再度 $-20^{\circ} \mathrm{C} て ゙ ~ 4$ 日間凍絬保存後菌数を測定した。この場 合は，菌数は $10^{2} \sim 10^{3}$ 代の低下を認めた。しかし，摘出 腎を直ちにホモジナイズした場合と， $-20^{\circ} \mathrm{C} ， 48$ 時間凍 結保存後ホモジナイズしな場合とを比べると，腎内全菌 数は後者でやや低值を示したが, No. 6 除いて全て $10^{7}$ 代であつたささらにNo. 6 が小膿瘍を1個だけ有して いたのに比し，他の 5 腎は多数の膿瘍を有していたこと を考虑すると， $-20^{\circ} \mathrm{C} ， 48$ 時間凍結保存による腎内全菌 数の変化は少ない之考兄られた (Table 2).

（2）腎病変 Grade と腎内全菌数について

ラット33元，66腎について腎凍結組織標本作製と腎内

Fig. 1 Low-photomicrograph of frozen sections-of rat kidney

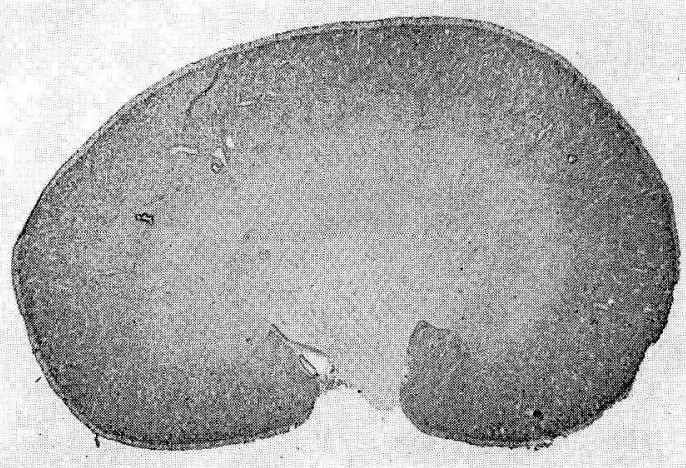

Grade 0: No inflammatory changes.

$\log _{10}$ No. of organisms per kidney: none

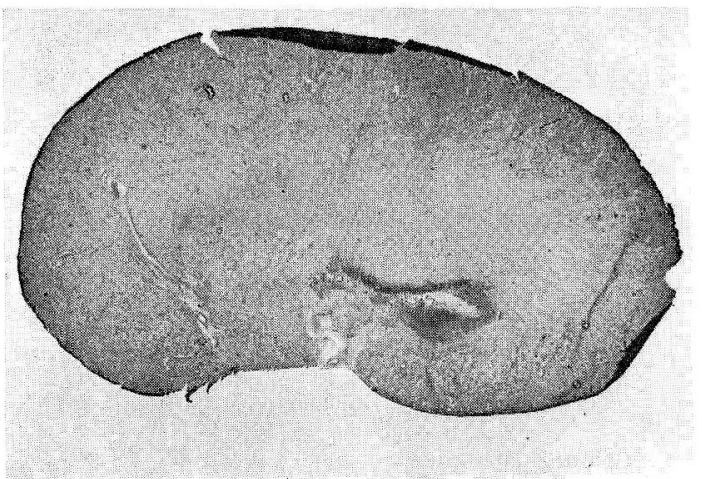

Grade II : The inflammatory changes extended into the corticomedullary area, especially at the fornix. $\log _{10}$ No. of organisms per kidey: 6.61

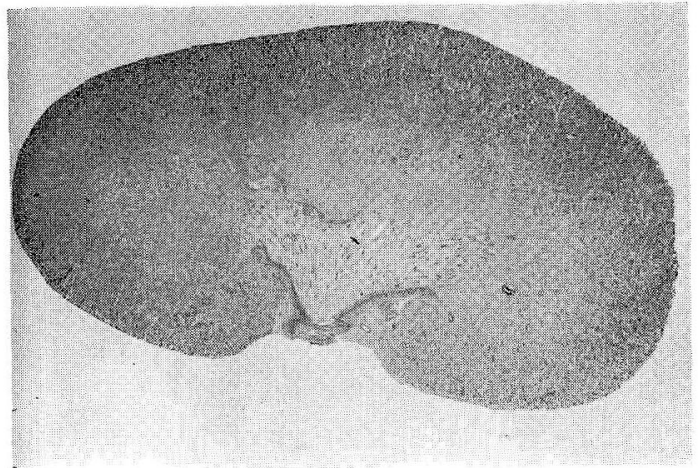

Grade I : The mild and early inflammatory changes were in the papilla and fornix.

$\log _{10}$ No, of organisms per kidney: 2.00

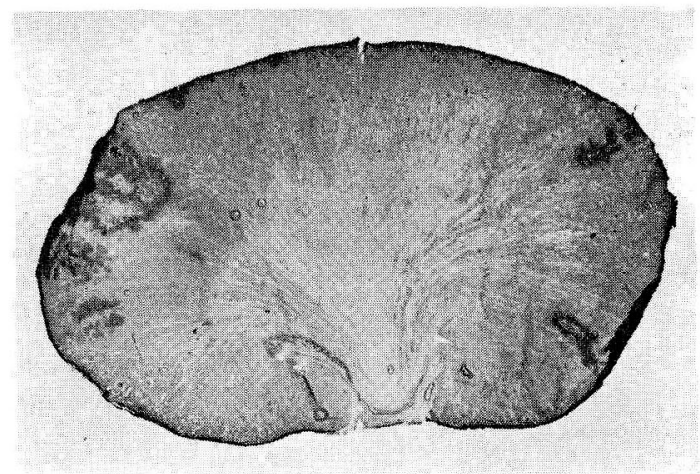

Grade III: The inflammatory changes extended into the cortical surface with abscess formation.

$\log _{10}$ No. of organisms per kidney: 7.99 
全菌数の測定を行なつた，居殺時 $\mathrm{Pm}$ 世膀脱からは全 例，腎では66腎中51腎から検出された，Pm が恰计され なかつた15腎中 2 腎のみ菌数測定時 $\mathrm{Pm}$ が検出された

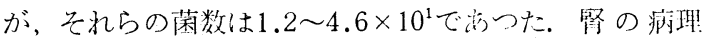

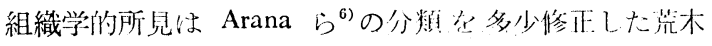
$ら^{5)}$ の分類に従つて判定した，即ち，Grade 0：炎病な し, Grade I : 炎症が腎盘内にとどまるもの, Grade II : 炎症が髄質内采大は軽度に皮質に浸潤するが皮質表而 まで澾していないもの, Grade III : 肉眼的, 組織学们に 皮質腫瘍を形成したもの，である。凍絬組織標本はホル マリン固定標本に比べ明膫さでやや劣るが，帮として白

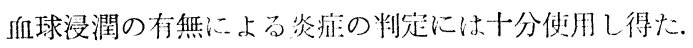

Fig. 1 に各Grade の湅結組織標本を示した。1:记の分 類に従つて腎病变 Grade 別に66婜の婜内全菌数を常用 対数で図示した. 即ち, 冬Grade における腎内全菌数の

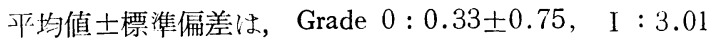
\pm 1.02 , II $: 5.78 \pm 0.85$, III $: 7.25 \pm 0.72$, であつた. Grade の進展と荣数の増加は上く並行し, 齐 Grade の 平均菌数閒に柱全て有意差 $(\mathrm{p}<0.001)$ を認队た（Fig. 2).

Fig. 2 Correlation between the pathological grades and the total number of bacteria in the kidneys

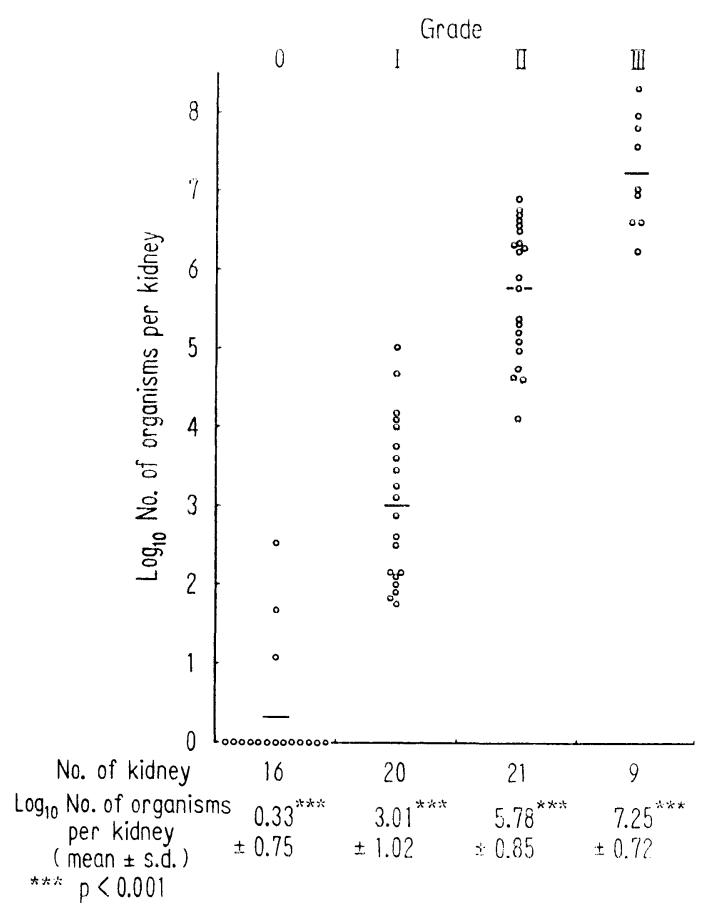

\section{考按}

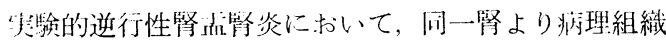
䧣本と菌数の雨者を得る往来の方法には，冒頭に述べた 如く，どちらが多少犠牲に与るという不満足な点が落

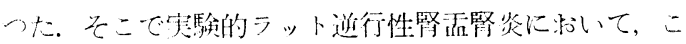

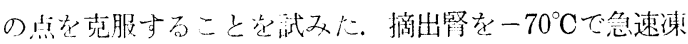

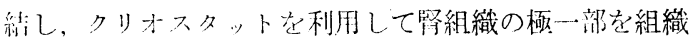
標本としてて使用し，残腎組織は削片も食て含めて $-20^{\circ} \mathrm{C}$ で48時開凍絬保存後藏数測定に使用することに上りほぼ

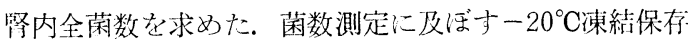
の影響は，TSB けの菌数では 2 淍閒不変で出りまた

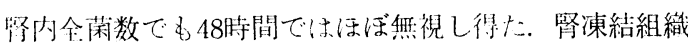
䧣木はホルマリン固定に上る組織標不に比べ，明瞭さて やや少るが，主として白的球浸潤の有無に上万炎症の判 定には十分使用し得た。以上上り，本法は同一繁上り病 理組織標本と婜内全菌数の雨者が得られ，乙か子菌数測 定を後日に行ならため，腎摘出当日を他の目的の実駼に 为使用し得る良い方法之考斻られる。

李た, 婜内菌数と腎病理組織標本とは，いずれも奉駼 们腎台腎炎の検索に必要なもので茄るが，菌数測定は後 者に比し，一般に時間と手間を要与る。一方，組織は速 続切片でもとら限り腎内の病变をすべて明らかに5る ことはできない，しかし，現䒠には多数の罗駼動物すべ

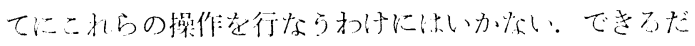
け簡监で病変の程度を的確に反映与る判运法が望まれる わけである. 教室の荒木ら ${ }^{5)}$ は Arana らの分類を多少修

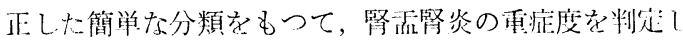
て来たが，今回の実験の結果，この分類法が腎内菻数と よく亚行することが判明した，良つて，䒠験的シット逆 行性腎孟腎炎の重症度判定で，少なくとも急性期で，抗 菌剂投与等の処置を施していない場合には, 腎内菌数在

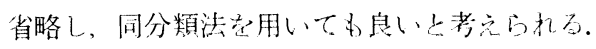

\section{結語}

（1）本法は，契験的ラット逆行性腎孟腎炎にわい， $\tau$, 同一婜上り病理組織標木上腎内全菌数の雨者等得る ために良い方法である。

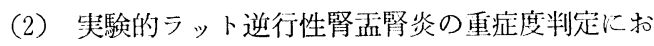
いて, 荒木らの分類は腎内全菌数と良く並行し，少なく とも急性期で，抗菌剤投与等の処置を施していない場合 は, 腎内菌数も省略し得る有用な分類法である。

\section{文献}

1) Cortran, R.S., Vivaldi, E., Zangwill, D.P. and Kass. E.H.: Retrograde proteus 
pyelonephritis in rats: Bacteriologic, pathologic and fluorescent-antibody studies. Am. J. Path., 43, 1-30, 1963.

2) Miller, T.E., Burnham, S. and North. J.D.K.: Immunological cnhancement in the pathogenesis of pyelonephritis. Clin. Exp. Immunol., 24, 336-345, 1976.

3) Hunter, B.W., Akins, L.L. and Sanford, J.P.: The role of immunity in the pathogenesis of experimental retrograde pyelonephritis. J. Exp. Med., 119, 869-879, 1964.
4) Brooks, S.J.D., Lyons, J.M. and Braude, A.1.: Immunization against retrograde pyelonephritis. Am. J. Path., 74, 345-364, 1974.

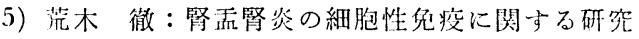
; 変形菌による実験的ラット逆行性腎孟腎炎に お计る adoptive immunity. 日泌尿令誌, 69, $771-779,1977$.

6) Arana, J.A., Kozij, V.M. and Jackson, G.G.: Retrograde E. coli urinary tract infection in rats. Arch. Path., 78, 558-567, 1964.

(1980年11月18日受付) 